\title{
Optimum Tilt Angles for Photovoltaic Panels during Winter Months in the Vaal Triangle, South Africa
}

\author{
Osamede Asowata*, James Swart, Christo Pienaar \\ Department of Electronic Engineering, Vaal University of Technology, Vanderbijlpark, South Africa. \\ Email: "asowatao@vut.ac.za
}

Received January $31^{\text {st }}, 2012$; revised February $27^{\text {th }}, 2012$; accepted March $4^{\text {th }}, 2012$

\begin{abstract}
Optimizing the output power of a photovoltaic panel improves the efficiency of a solar driven energy system. The maximum output power of a photovoltaic panel depends on atmospheric conditions, such as (direct solar radiation, air pollution and cloud movements), load profile and the tilt and orientation angles. This paper describes an experimental analysis of maximizing output power of a photovoltaic panel, based on the use of existing equations of tilt angles derived from mathematical models and simulation packages. Power regulation is achieved by the use of a DC-DC converter, a fixed load resistance and a single photovoltaic panel. A data logger is used to make repeated measurements which ensure reliability of the results. The results of the paper were taken over a four month period from April through July. The photovoltaic panel was set to an orientation angle of $0^{\circ}$ with tilt angles of $16^{\circ}, 26^{\circ}$ and $36^{\circ}$. Preliminary results indicate that tilt angles between $26^{\circ}$ and $36^{\circ}$ provide optimum photovoltaic output power for winter months in South Africa.
\end{abstract}

Keywords: Solar Energy; Optimum; Orientation Angle; Tilt Angle; Data Logger; Photovoltaic (PV) Panel

\section{Introduction}

Einstein said, "the release of energy has not created a new problem, but has made more urgent the necessity of solving an existing one"' [1]. In the quest to harness clean cheap energy from the sun, a phenomenon was discovered in the early $19^{\text {th }}$ century, where electrical energy is generated using the photovoltaic (PV) effect [2]. The sun is approximately 1.4 million $\mathrm{km}$ in diameter and 150 million $\mathrm{km}$ from the earth. It has a surface temperature close to $5500^{\circ} \mathrm{C}$ and it radiates energy at a rate of $3.8 \times 10^{23} \mathrm{~kW}$ per second on an average daily basis [3]. Solar energy is supplied by nuclear fusion reactions near its core which are estimated to continue for several billion years.

Solar energy can be converted directly into electricity with modules consisting of PV cells. Electricity is usually manufactured from fine film semiconductor devices capable of converting direct solar radiation into DC current. The efficiency of PV cells varies from 3\% to $31 \%$, depending on the technology, the light spectrum, atmospheric condition, temperature, design and the material used [4].

There are numerous isotropic and anisotropic mathematical models, equations of latitude and simulation packages that can estimate the optimum tilt and orientation angle of a PV panel for given latitude on earth. How-

${ }^{*}$ Corresponding author. ever, little real experimental data or no real consistency exists with which to verify the suggested values for specific areas of latitude and longitude in South Africa. This proves problematic for the successful installation of PV panels for optimum output power.

The purpose of this study is to optimize the available output power from a PV panel for a specific point of latitude in South Africa. Mathematical models and simulation packages in combination with experimental data were used to determine the optimum tilt and orientation angles. This will enable a higher yield of solar energy, thereby reducing dependence on traditional energy sources such as fossil fuels. This study aims to identify ways of improving the installation of $\mathrm{PV}$ panels for optimum annual output power. A designed experimental approach involving quantitative data and descriptive statistics is used in this research. Figure 1 illustrates the tilt (y) and orientation angles $(\alpha)$ of a single PV panel.

The paper firstly presents literature relating to the different PV panels that exist, and then introduces the empirical test which was used with different tilt angles as suggested by Heywood and Chinnery equations of latitude. The research methodology is explained and initial results are presented in a number of graphs and tables. Statistical $\mathrm{R}^{2}$ values are obtained from the data derived from the different tilt angles which are used to formulate the conclusions. 


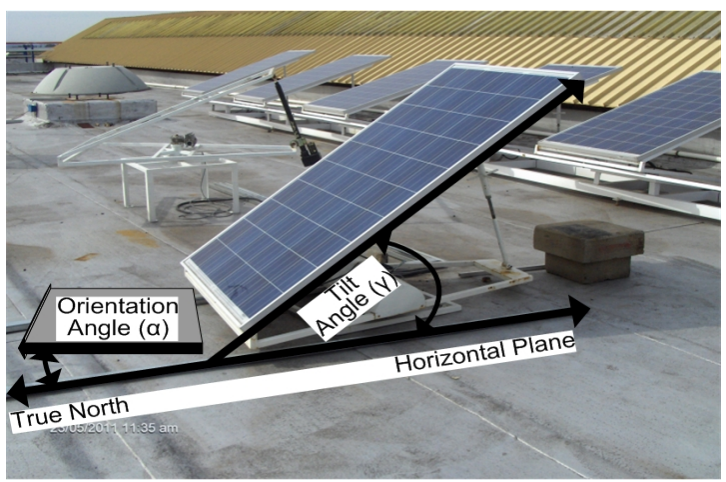

Figure 1. Tilt and orientation angles of a PV panel.

\section{Photovoltaic (PV) Panels}

Three different types of PV panel modules basically exist, namely the mono-crystalline, the poly-crystalline (or multicrystalline) and the amorphous silicon panels [5].

\subsection{Mono-Crystalline}

In mono-crystalline PV panels, cells are cut from a single crystal of silicon [6]. It has a smooth texture which makes the thickness of the slice visible. They are rigid and must be mounted in a secure frame to protect them. The principle advantage of mono-crystalline cells are their high efficiencies, typically around $15 \%$, although the manufacturing process required to produce mono-crystalline silicon is complicated, resulting in slightly higher costs than other technologies [7]. Figure 2 presents a photograph of a mono-crystalline cell while Table 1 indicates selected parameters for this type of PV panel.

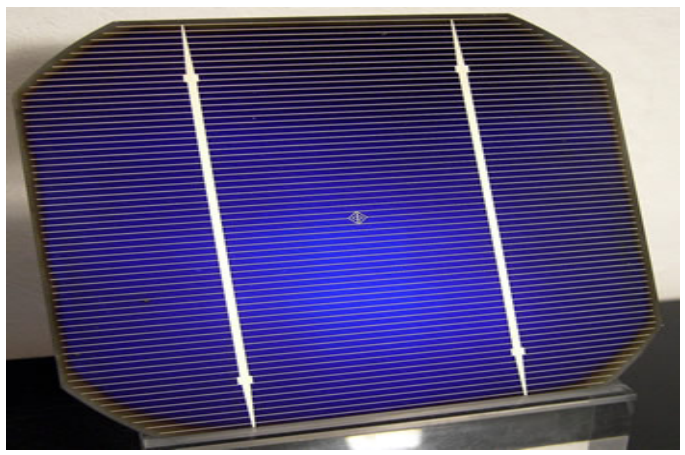

Figure 2. A cell of a mono-crystalline PV panel.

Table 1. ZKX-160D-2 module/160Wp-180Wp mono-crystalline PV panel.

\begin{tabular}{ccc}
\hline Specification & Abbreviation & Value \\
\hline Maximum output power & $\mathrm{P}_{\mathrm{MAX}}$ & $160 \mathrm{~W}$ \\
Open circuit voltage & $\mathrm{V}_{\mathrm{OC}}$ & $42.8 \mathrm{~V}$ \\
Rated voltage & $\mathrm{V}_{\mathrm{MPP}}$ & $34.9 \mathrm{~V}$ \\
Short circuit current & $\mathrm{I}_{\mathrm{SC}}$ & $5.15 \mathrm{~A}$ \\
Rated current & $\mathrm{I}_{\mathrm{MPP}}$ & $5.03 \mathrm{~A}$ \\
\hline
\end{tabular}

\subsection{Poly-Crystalline}

Poly-crystalline (or multi-crystalline) cells are made from a slice cut from a block of silicon consisting of a large number of crystals [6]. They have a speckled reflective appearance which makes the thickness of the slice visible. In the manufacturing process, molten silicon is cast into ingots of poly-crystalline silicon; these ingots are then saw-cut into very thin wafers and assembled into complete cells [7]. These cells are slightly less efficient, (average efficiencies of around 12\%) and slightly less expensive than mono-crystalline cells, but also need to be mounted in a secure frame. Figure 3 presents a photograph of a poly-crystalline cell while Table 2 indicates selected parameters for this type of PV panel.

\subsection{Amorphous Silicon}

These panels are also known as amorphous silicon (a-Si) PV panels [8] (see Figure 4 for an example). Amorphous silicon was first deposited from a silane discharge by

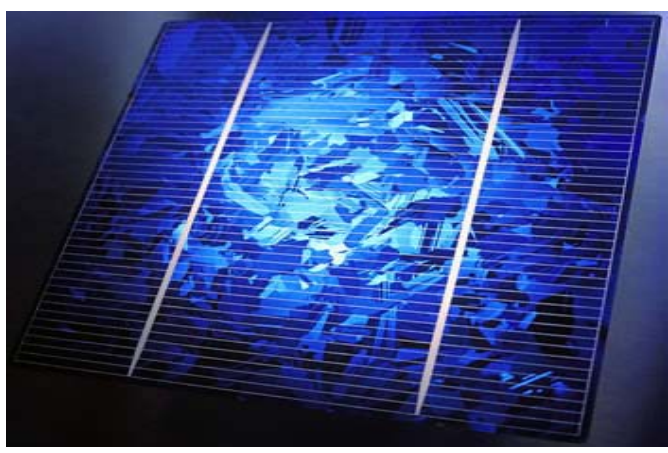

Figure 3. A cell of a poly-crystalline PV panel.

Table 2. Sun module SW220 poly-crystalline PV panel.

\begin{tabular}{ccc}
\hline Specification & Abbreviation & Value \\
\hline Maximum output power & $\mathrm{P}_{\mathrm{MAX}}$ & $220 \mathrm{~W}$ \\
Open circuit voltage & $\mathrm{V}_{\mathrm{OC}}$ & $36.6 \mathrm{~V}$ \\
Rated voltage & $\mathrm{V}_{\mathrm{MPP}}$ & $29.2 \mathrm{~V}$ \\
Short circuit current & $\mathrm{I}_{\mathrm{SC}}$ & $8.08 \mathrm{~A}$ \\
Rated current & $\mathrm{I}_{\mathrm{MPP}}$ & $7.54 \mathrm{~A}$ \\
\hline & & \\
\end{tabular}

Figure 4. A cell of an amorphous silicon PV panel. 
Chittik et al. in 1969. The progress in a-Si solar cell technology can be attributed to technological advances over the last few decades [7]. The optoelectronic properties of amorphous PV panels vary over a wide range and are highly influenced by plasma deposition conditions [8]. Amorphous silicon PV panels are fabricated in a laboratory with a wide variety of different structures, but most commercial products utilize $\mathrm{p}-\mathrm{i}-\mathrm{n}$ or $\mathrm{n}-\mathrm{i}-\mathrm{p}$ junctions. Multi-junction devices are also being designed to take advantage of a broader spectrum of the sun's rays and to maximize efficiency [9]. They are the least efficient and least expensive to produce of the three different panels discussed in this paper. Due to the amorphous nature of the thin layer, it is flexible, and can be used to manufacture flexible PV panels. A poor characteristic of amorphous solar cells is that their power output reduces over time [7]. Table 3 indicates selected parameters for this type of PV panel.

A Sun module SW220 poly-crystalline PV panel is used in this research due to its lower cost and better performance in areas of direct solar radiation.

\section{Test System}

Figure 5 shows a block diagram of the test system which comprises a PV panel connected to a DC-DC converter and a constant load resistance (Figure 6 shows a photograph). Determining the optimum tilt angle involves placing the PV panel at an orientation angle of $0^{\circ}$ and changing the angle of tilt to $16^{\circ}, 26^{\circ}$ and $36^{\circ}$ respectively. These angles are derived from the Heywood and Chinnery equations of latitude for calculating tilt angles of PV panels in South Africa. Vanderbijlpark lies on latitude of $26^{\circ}$ south and longitude $27^{\circ}$ east, giving the mathematical results for tilt angles as shown in Table 4.

Table 3. Amorphous silicon thin film PV Panel (a-Si PV module).

\begin{tabular}{ccc}
\hline Specification & Abbreviation & Value \\
\hline Maximum output power & $\mathrm{P}_{\mathrm{MAX}}$ & $41 \mathrm{~W}$ \\
Open circuit voltage & $\mathrm{V}_{\mathrm{OC}}$ & $58 \mathrm{~V}$ \\
Rated voltage & $\mathrm{V}_{\mathrm{MPP}}$ & $44 \mathrm{~V}$ \\
Short circuit current & $\mathrm{I}_{\mathrm{SC}}$ & $1.20 \mathrm{~A}$ \\
Rated current & $\mathrm{I}_{\mathrm{MPP}}$ & $0.94 \mathrm{~A}$ \\
\hline
\end{tabular}

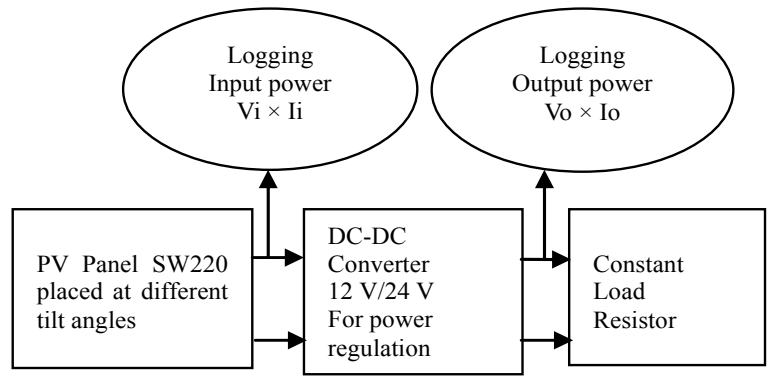

Figure 5. Block diagram of the practical set-up.

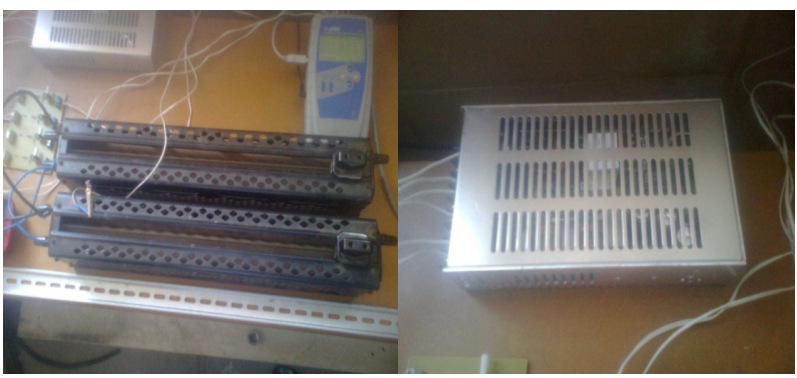

Load resistance

DC-DC converter

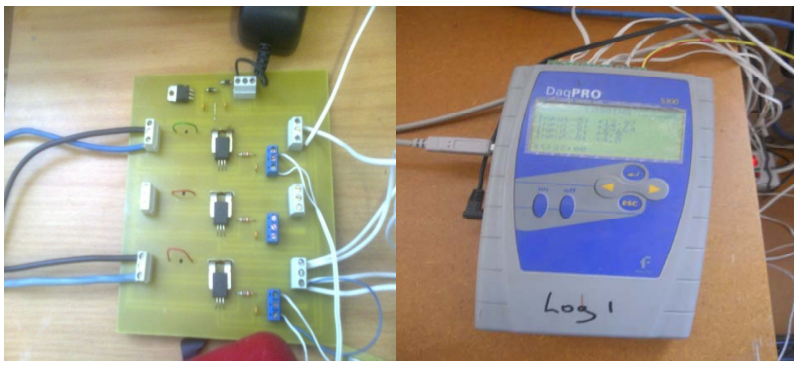

Data logging interface circuit

DAQ pro 5300 logger

Figure 6. Photograph of the practical set-up.

Table 4. Calculation of tilt angles.

\begin{tabular}{cccc}
\hline $\begin{array}{c}\text { Latitude of } \\
\text { VUT }\end{array}$ & $\begin{array}{c}\text { Heywood and } \\
\text { Chinnery Equation }\end{array}$ & $\begin{array}{c}\text { Calculation } \\
\text { For VUT }\end{array}$ & $\begin{array}{c}\text { Tilt angles } \\
\text { Used at VUT }\end{array}$ \\
\hline $26^{\circ}$ & $\Phi-10$ & $26^{\circ}-10^{\circ}$ & $16^{\circ}$ \\
$26^{\circ}$ & $\Phi$ & $26^{\circ}$ & $26^{\circ}$ \\
$26^{\circ}$ & $\Phi+10$ & $26^{\circ}+10^{\circ}$ & $36^{\circ}$ \\
\hline
\end{tabular}

A $12 \mathrm{~V}$ and $24 \mathrm{~V}$ DC-DC converter is used to regulate the output power from the PV panel. A DAQ pro 5300 data logger is used to collect measurements (input voltage, output voltage, input current and output current). The experiment is repeated taking four samples each using the $16^{\circ}, 26^{\circ}$ and $36^{\circ}$ tilt angles. These samples ensure testretest reliability of the measuring instrument which must be administered on at least two occasions [10].

Atmospheric conditions in terms of industrial pollution [11] and cloud movement affect the performance of PV panels, and therefore have a direct bearing on the total number of complete samples which must be collected [12]. This is seen in Figure 7 where cloud movement interrupts the direct solar radiation from the sun for a particular day, these values are not averaged. It is difficult to account accurately for these factors and may require additional samples.

\section{Initial Results}

Regression analysis is modeling the relationship between a scalar variable $y$ and one or more variables denoted $x$ [13]. The polynomial regression is a form of linear regression in which the relationship between the independent variable $\mathrm{x}$ (time) and the dependent variable $\mathrm{y}$ 


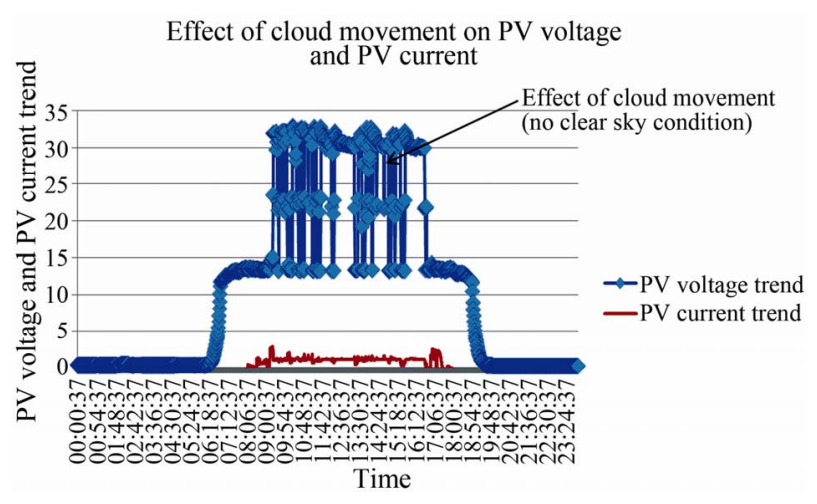

Figure 7. Effect of cloud movement on direct solar radiation received by a PV panel.

(voltage) is modeled. A regression analysis of the linear equation is used to obtain the $\mathrm{R}^{2}$ value for the average conversion-time per week. This enables one to establish a relationship between the DC-DC converter voltage and the conversion-time per week. A linear regression trend analysis, using a polynomial 6 , would be used to obtain the $\mathrm{R}^{2}$ value for the average work-time per day. This enables one to establish a relationship of the variability between the DC-DC converter voltage and the average work-time per day. The $\mathrm{R}^{2}$ value in each case helps predict how well the value of the conversion-time predicts the value of the DC-DC converter voltage.

True north is determined using a GARMIN Etrex GPS handheld device. The PV panel is orientated parallel to this direction resulting in an orientation angle of $0^{\circ}$. Exact longitude and latitude angles for the installation of the single PV panel on the roof of the S-Block at Vaal University of Technology (VUT) are obtained with this device (Latitude: $26^{\circ} 42^{\prime} 649^{\prime \prime S}$ and Longitude: $27^{\circ} 51^{\prime} 809^{\prime \prime} \mathrm{E}$ ). Preliminary results for open circuit voltages using tilt angles of $6^{\circ}, 16^{\circ}$ and $26^{\circ}$ are presented in Figures 8-10 respectively.

All three tilt angles provided an open circuit output voltage of approximately $36 \mathrm{~V}$ from about $6 \mathrm{AM}$ to around 7 PM. This coincides with the manufacturing specifications shown in Table 2. These results further show that as the

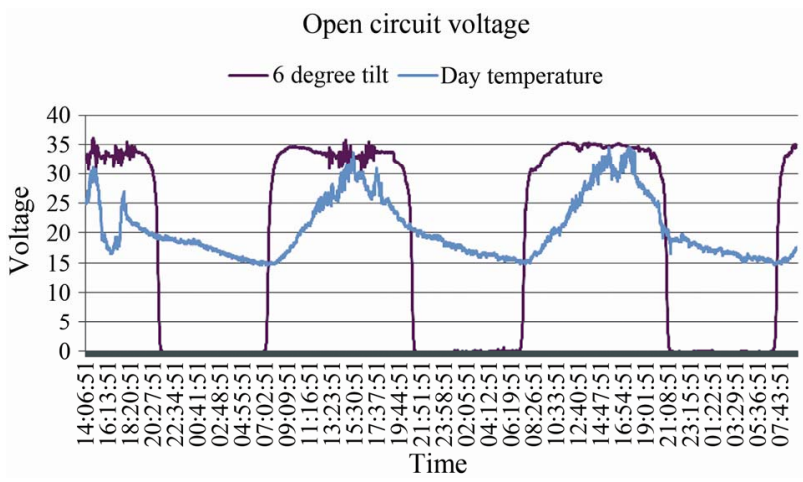

Figure 8. Open circuit voltage for a tilt angle of $16^{\circ}$.

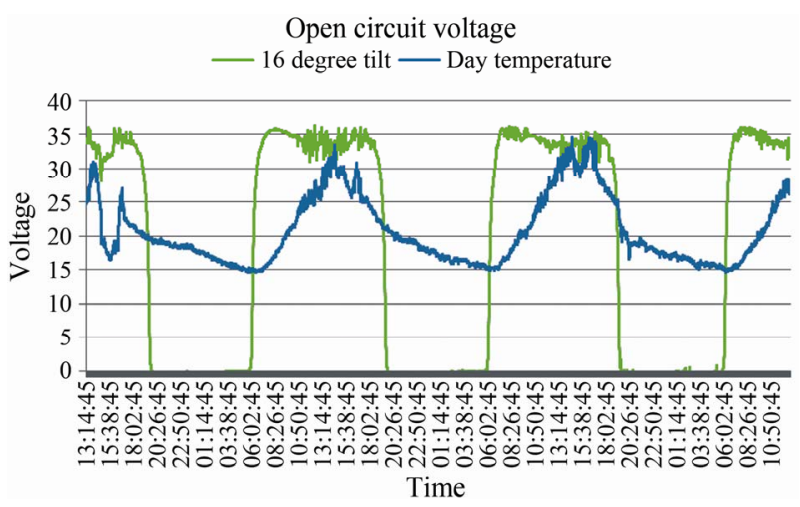

Figure 9. Open circuit voltage for a tilt angle of $16^{\circ}$.

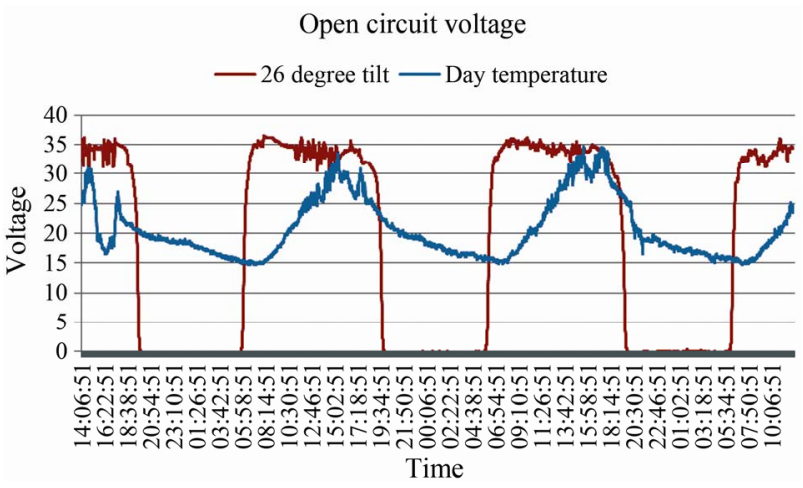

Figure 10. Open circuit voltage for a tilt angle of $26^{\circ}$.

day temperature increases, the output voltage of the PV panel decreases. This phenomenon is known as temperature degradation.

Figure 11 presents the average conversion-time for the 22-29 April 2011, where a 24 V DC-DC converter was used with the PV panel placed at a tilt angle of $26^{\circ}$ and an orientation angle of $0^{\circ}$. The conversion-time of the system (the time which power is being delivered to the load) is derived with a normal probability plot using MS EXCEL in the Data Analysis Toolpak. Regression analysis can be used for process optimization [13]. The point at

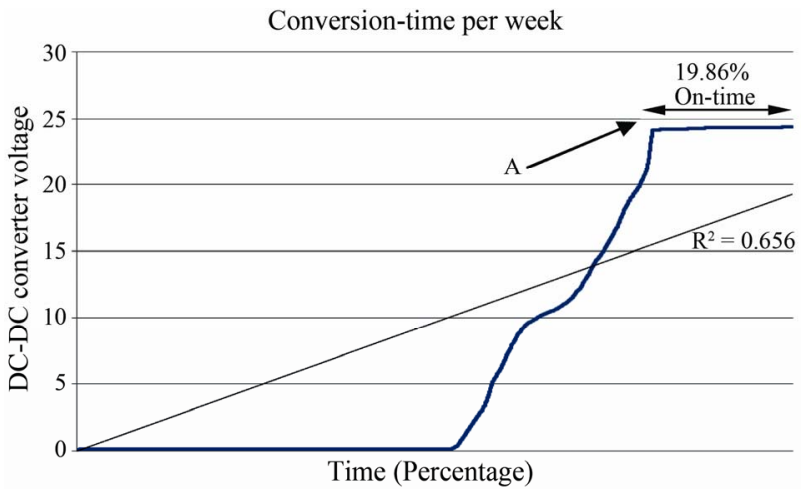

Figure 11. Regression analysis (linear) of the data obtained for the 22-29 April 2011 (24 V DC-DC converter/PV panel placed at a tilt angle of $26^{\circ}$ ). 
which power is delivered to the load is indicated as point $\mathrm{A}$ and represents the start of the conversion-time (being $19.68 \%$ for this given week). Point A on the $\mathrm{Y}$-axis gives a value of about $24 \mathrm{~V}$ which coincides with the output voltage specification of the DC-DC converter.

A linear trend line specifies a statistical $R^{2}$ value of 0.656 that indicates the relationship between the average conversion-time of the system and the direct solar radiation received from the sun. The average sun hours per day for this specific week may be calculated as follows:

Sun hours per day $=24$ hours $\times$ AveOnTime

$$
\begin{aligned}
& \text { Sun hours per day }=\frac{24 \text { hours } \times 19.68 \%}{100} \\
& \text { Sun hours per day }=4.72 \text { hours }
\end{aligned}
$$

A regression analysis (Polynomial 6) is done in Figure 12 to obtain the average work-time per day for a set of data taken over a week period, from the 22-29 April 2011. A $24 \mathrm{~V}$ DC-DC converter was used. The $\mathrm{R}^{2}$ value is 0.845 , which shows how well the resulting line matches the original data points. It is also a statistical value that indicates the strength of the relationship between the average work-time per day and the direct solar radiation received from the sun. The wider the response (higher average work-time) the lower the $\mathrm{R}^{2}$ value.

Figure 13 shows the average conversion-time for the

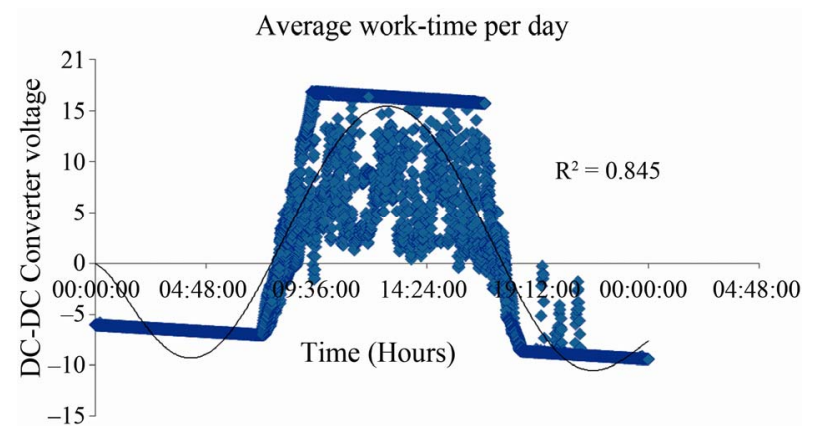

Figure 12. Average work-time per day 22-29 April 2011 (24 V DC-DC converter/PV panel placed at a tilt angle of $26^{\circ}$ ).

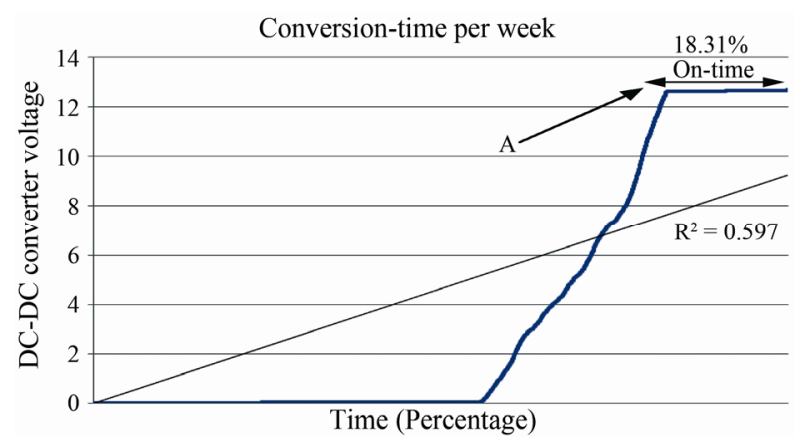

Figure 13. Regression analysis (linear) of the data obtained for the 8-15 July 2011 (12 V DC-DC converter/PV panel placed at a tilt angle of $16^{\circ}$ ).
8-15 July 2011, where a 12 V DC-DC was used with the PV panel placed at $16^{\circ}$ and an orientation angle of $0^{\circ}$. This enables comparison with the $24 \mathrm{~V} \mathrm{DC}-\mathrm{DC}$ converter in order to establish validity. Point A indicates the point where the DC-DC converter starts delivering power to the load, and is seen as an output voltage of $12 \mathrm{~V}$ on the $\mathrm{Y}$-axis which coincides with the specification of the DCDC converter. This analysis shows an average conversion-time of $18.31 \%$. This is derived from adding a data label at point A, using MS EXCEL. This equates to the percentage of available solar radiation for that specific week. A linear trend line indicates a statistical $\mathrm{R}^{2}$ value of 0.597 . This value illustrates the strength of the relationship and the proportion of variability between the average conversion-time and the available solar radiation received. The DC-DC converter supplied power to the load for about $18.31 \%$ of the week which equates to the percentage of available solar radiation (sun hours) for that specific week as follows:

$$
\begin{aligned}
& \text { Sun hours per day }=24 \text { hours } \times \text { AveOnTime } \\
& \text { Sun hours per day }=\frac{24 \text { hours } \times 18.31 \%}{100} \\
& \text { Sun hours per day }=4.39 \text { hours }
\end{aligned}
$$

The regression analysis (polynomial 6) to obtain the average work-time per day of a $12 \mathrm{~V} \mathrm{DC}$-DC converter for the 8-15 July 2011 is presented in Figure 14.

The $\mathrm{R}^{2}$ value is 0.903 , which indicates how well the resulting line matches the original data points. It's also a statistical value that indicates the strength of the relationship between the average work-time per day and the direct solar radiation received. In this case, as compared to Figure 12, it is seen that the narrower the response of the curve (lower average work-time), the higher the $\mathrm{R}^{2}$ value.

These individual results were collated with the other results obtained for each week of data collected over a four month period from April through July of 2011. The analysis of this 12 week period is shown in Table 5, where the data is ranked according to the regression trend value.

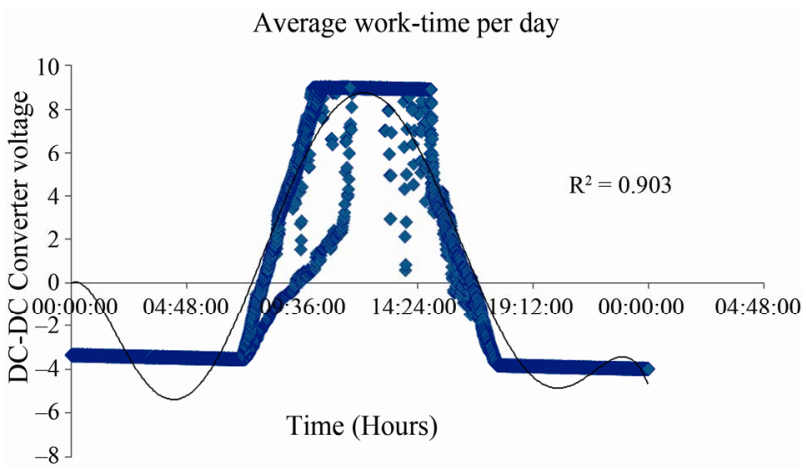

Figure 14. Average work-time per day 8-15 July 2011 (12 V DC-DC converter/PV panel placed at a tilt angle of $16^{\circ}$ ). 
Table 5. Set of data for the months of April through July using $12 \mathrm{~V}$ and $24 \mathrm{~V}$ DC-DC converters.

\begin{tabular}{ccccc}
\hline $\begin{array}{c}\text { Regression } \\
\text { trend value }\end{array}$ & $\begin{array}{c}\text { Week } \\
\text { ending }\end{array}$ & $\begin{array}{c}\text { DC-DC } \\
\text { converter } \\
\text { voltage }\end{array}$ & Tilt angle & $\begin{array}{c}\text { Conversion-time/ } \\
\text { wk as a } \\
\text { percentage }\end{array}$ \\
\hline 0.567 & 20-May & $24 \mathrm{~V}$ & $16^{\circ}$ & $2.84 \%$ \\
0.573 & 29-July & $12 \mathrm{~V}$ & $16^{\circ}$ & $11.53 \%$ \\
0.577 & 13-May & $24 \mathrm{~V}$ & $16^{\circ}$ & $2.52 \%$ \\
0.597 & 15-July & $12 \mathrm{~V}$ & $16^{\circ}$ & $18.31 \%$ \\
0.609 & 27-May & $24 \mathrm{~V}$ & $36^{\circ}$ & $10.07 \%$ \\
0.611 & 22-April & $24 \mathrm{~V}$ & $36^{\circ}$ & $8.76 \%$ \\
0.616 & 24-June & $12 \mathrm{~V}$ & $26^{\circ}$ & $20.2 \%$ \\
0.623 & 6-May & $24 \mathrm{~V}$ & $26^{\circ}$ & $16.19 \%$ \\
0.629 & 1-July & $12 \mathrm{~V}$ & $26^{\circ}$ & $19.81 \%$ \\
0.631 & 10-June & $12 \mathrm{~V}$ & $36^{\circ}$ & $14.94 \%$ \\
0.632 & 17-June & $12 \mathrm{~V}$ & $36^{\circ}$ & $19.74 \%$ \\
0.656 & 29-April & $24 \mathrm{~V}$ & $26^{\circ}$ & $19.68 \%$ \\
\hline
\end{tabular}

This regression trend line value (linear) indicates the relationship between the average conversion-time (actual direct solar radiation received the PV panel for each week) and the output voltage of the DC-DC converter.

\section{Future Work}

A new practical set-up comprising three identical PV panels (each set to a different tilt angle of $16^{\circ}, 26^{\circ}$ and $36^{\circ}$ ) connected to identical solar chargers and load resistances have been installed. This will expose the PV panels to the same solar radiation and environmental factors that influence their output power. This would enable an accurate comparison of the data collected for each tilt angle, thereby establishing validity. Figure 15 shows a picture of the three identical PV panel set to different tilt angles which have been installed on the roof of the SBlock at VUT.

\section{Conclusions}

In review, the purpose of this research is to optimize the

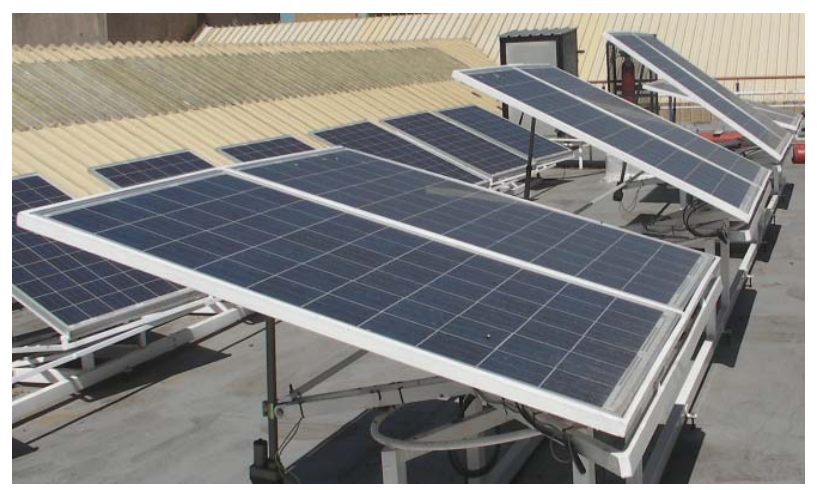

Figure 15. Three identical solar panels set to tilt angles of $16^{\circ}, 26^{\circ}$ and $36^{\circ}$ degrees. available output power from a PV panel, based on different tilt and orientation angles. The orientation angle is initially fixed at $0^{\circ}$, with only the tilt angle being varied. Optimizing the output power will enable a higher yield of solar energy, thereby reducing dependence on traditional energy sources such as fossil fuels. The availability of power was interpreted showing the average conversiontime for the 22-29 April 2011 and for the 8-15 July 2011 (being $19.68 \%$ and $18.31 \%$ respectively, see Figures 11 and 13). The average conversion-time per week, for the months of April through July with tilt angles of $16^{\circ}, 26^{\circ}$ and $36^{\circ}$ and a fixed orientation angle of $0^{\circ}$ is presented in Table 5. From the results gathered, doing a linear regression analysis reveals that generally the higher the average conversion-time per week the higher the $\mathrm{R}^{2}$ value. A comparison between Figures 12 and $\mathbf{1 4}$ reveals that the values of the linear trend value (polynomial 6) are not similar. This is because Figure 12 represents a broader response curve (higher average work-time per day giving an $\mathrm{R}^{2}$ value of 0.845 ) than Figure 14 (lower average work-time per day giving an $\mathrm{R}^{2}$ value of 0.903 ).

The peak winter months in South Africa are June and July, which indicated the highest regression trend value (linear) for $26^{\circ}$ and $36^{\circ}$ tilt angles (see Table 5). This coincides with earlier endeavors to calculate the proper choice of tilt angles using mathematical and simulation models based on the research done by Chinnery [14]. These initial experimental results therefore prove the validity and reliability of these models for winter months in the Vaal Triangle, South Africa.

\section{REFERENCES}

[1] A. Einstein, “Albert Einstein Quotes, 1879-1995," Accessed on 30 May 2011.

http//www.phnet.fi/public/mamma1/einstein.htm

[2] M. Boxwell, "Solar Electricity Handbook, a Simple Practical Guide to Solar Energy-Designing and Installing Photovoltaic Solar Electric Systems," 2nd Edition, Code Green publishing, London, 2010, p. 3.

[3] K. Lovegrove and M. Dennis, "Solar Thermal Energy Systems in Australia," International Journal of Environmental Studies, Vol. 63, No. 6, 2006, pp. 791-802. doi:10.1080/00207230601047156

[4] F. A. Farret and M. G. Simoes, "Integration of Alternative Sources of Energy," John Wiley Press, Hoboken, 2006, p. 129. doi:10.1002/0471755621.ch6

[5] Hub Pages, Accessed on 28 October 2011 http://akihan.hubpages.com/hub/types-of-pv-cells

[6] Solar Facts, Accessed on 29 November 2011. http://www.solar-facts.com/panels/panel-types.php

[7] Moukd. Information about Different Types of Solar Panels, Accessed on 30 October 2011. http://www.moukd.com

[8] T. Markvart and L. Castaner, "Practical Handbook of Photovoltaic Fundamentals and Application," Elsevier 
Press, Oxford, 2005, pp. 284-289.

[9] Solar Always, Accessed on 30 October 2011. http://www.solaralways.com/types/solar-panels

[10] C. Welman, F. Kruger and B. Mitchell, "Research Methodology," Oxford University Press, Oxford, 2005, p. 146.

[11] A. J. Swart, R. M Schoeman and H. C. Pienaar, "Assessing the Effect of Variable Atmospheric Conditions on the Performance of Photovoltaic Panels: A Case Study from the Vaal Triangle," Southern African Energy Convention, Southern African Energy Effciency Convention (SAEEC), Johannesburg, 16-17 November 2011, pp. 1-6.

[12] S. Mashorhor, K. Samsudin, A. M. Noor and A. R. A. Rah- man, "Evaluation of Genetic Algorithm Based Solar Tracking System for Photovoltaic Panels,', IEEE International Conference on Sustainable Energy Technologies, Singapore City, 24-28 November 2008, pp. 269-273.

[13] D. C. Montgomery and G. C. Runger, "Applied Statistics and Probability for Engineers," 5th Edition, John Wiley \& Sons, Hoboken, 2011.

[14] S. Armstrong and W. G. Hurleya, "A New Methodology to Optimise Solar Energy Extraction under Cloudy Conditions," Renewable Energy, Vol. 35, No. 4, 2009, pp. 780787. doi:10.1016/j.renene.2009.10.018 